\title{
Correction to: Stepping forward and taking reverse as we move ahead in genetics
}

\author{
Ashwani Pareek $^{1} \cdot$ Ajay Arora $^{2} \cdot$ Om Parkash Dhankher ${ }^{3}$
}

Published online: 5 January 2019

(C) Indian Society for Plant Physiology 2019

\section{Correction to: Ind J Plant Physiol. https://doi.org/ 10.1007/s40502-018-0428-y}

In the original publication of the article, the references were missing and the authors would like to update the references. The references are mentioned below.

The original article has been corrected.

\section{References}

Badigannavar, A., Teme, N., de Oliveira, A. C., Li, G., Vaksmann, M., Viana, V. E., et al. (2018). Physiological, genetic and molecular basis of drought resilience in sorghum [Sorghum bicolor (L.) Moench]. Indian Journal of Plant Physiology. https://doi.org/10.1007/s40502-018-0416-2.

Bahuguna, R. N., Gupta, P., Bagri, J., Singh, D., Dewi, A. K., Tao, L., et al. (2018). Forward and reverse genetics approaches for combined stress tolerance in rice. Indian Journal of Plant Physiology. https://doi.org/10.1007/s40502-018-0418-0.

Chen, Y., Rengel, Z., Palta, J., \& Siddique, K. H. M. (2018). Efficient root systems for enhancing tolerance of crops to water and phosphorus limitation. Indian Journal of Plant Physiology. https://doi.org/10.1007/s40502-018-0415-3.

The original article can be found online at https:// doi.org/10.1007/s40502-018-0428-y.

Ashwani Pareek

ashwanip@mail.jnu.ac.in

1 Stress Physiology and Molecular Biology Laboratory, School of Life Sciences, Jawaharlal Nehru University, New Delhi 110067, India

2 Division of Plant Physiology, Indian Agricultural Research Institute, New Delhi 110012, India

3 Stockbridge School of Agriculture, University of Massachusetts, Amherst, MA 01003, USA
Dutt, S., Kirti, S., Vaidya, T., Parkash, J., Kashyap, S., Sharma, N., et al. (2018). External application of NADPH enhances biomass accumulation, seed germination and modulates expression of oxidative pentose phosphate pathway genes in Arabidopsis. Indian Journal of Plant Physiology. https://doi.org/10.1007/ s40502-018-0420-6.

Kaur, A., Vishwakarma, H., Maibam, A., \& Padaria, J. C. (2018). Cloning, characterization and in silico studies on abiotic stress responsive Hsp17.9 from Prosopis cineraria. Indian Journal of Plant Physiology. https://doi.org/10.1007/s40502-018-0414-4.

Kishor, P. B. K., Venkatesh, K., Amareshwari, P., Kumari, P. H., Punita, D. L., Kumar, S. A., et al. (2018). Genetic engineering for salt and drought stress tolerance in peanut (Arachis hypogaea L.). Indian Journal of Plant Physiology. https://doi.org/10.1007/ s40502-018-0421-5.

Kumar, A., \& Jain, S. (2018). Forward genetics using radiation hybrids (deletion mutants) in plants. Indian Journal of Plant Physiology. https://doi.org/10.1007/s40502-018-0419-z.

Kumar, K., Mosa, K. A., Meselhy, A. G., \& Dhankher, O. P. (2018). Molecular insights into the plasma membrane intrinsic proteins roles for abiotic stress and metalloids tolerance and transport in plants. Indian Journal of Plant Physiology. https://doi.org/10. 1007/s40502-018-0425-1.

Lakra, N., Kaur, C., Anwar, K., Singla-Pareek, S. L., \& Pareek, A. (2018). Proteomics of contrasting rice genotypes: Identification of potential targets for raising crops for saline environment. Plant, Cell and Environment, 41(5), 947-969.

Mishra, \& Kant, T. (2018). A simple, inexpensive, scalable and low maintenance hydroponics system for growing halophyte: Lepidium sativum L. (Brassicaceae), ideal for manipulating salt stress and inferring gene expression levels. Indian Journal of Plant Physiology. https://doi.org/10.1007/s40502-018-0422-4.

Mishra, M. K., Awati, M., Anand, C., \& Kumar, A. (2018). Molecular and physiological characterization of a natural interspecific coffee hybrid. Indian Journal of Plant Physiology. https://doi. org/10.1007/s40502-018-0410-8.

Nongpiur, R. C., Singla-Pareek, S. L., \& Pareek, A. (2016). Genomics approaches for improving salinity stress tolerance in crop plants. Current Genomics, 17(4), 343-357.

Pareek, A., Sopory, S. K., Bohnert, H., \& Govindjee, (Eds.). (2010). Abiotic stress adaptation in plants. Physiological, molecular and genomic foundation. Dordrecht: Springer. https://doi.org/10. 1007/978-90-481-3112-9. 
Prathi, N. B., Salim, A. P., Beena, R., Achuthan, V. P., \& Abdulla, N. P. (2018). Morpho-physiological and proteomic analysis to identify and characterise the traditional rice genotypes for drought tolerance. Indian Journal of Plant Physiology. https:// doi.org/10.1007/s40502-018-0405-5.

Priya, M., Siddique, K. H. M., Dhankhar, O. P., Prasad, P. V. V., Rao, B. H., Nair, R. M., et al. (2018). Molecular breeding approaches involving physiological and reproductive traits for heat tolerance in food crops. Indian Journal of Plant Physiology. https://doi. org/10.1007/s40502-018-0427-z.

Pushpalatha, G., \& Kumar, G. H. (2018). Gene expression analysis reveals diversified responsiveness to salt stress in rice genotypes. Indian Journal of Plant Physiology. https://doi.org/10.1007/ s40502-018-0424-2.

Sinha, R., Pal, A. K., \& Singh, A. K. (2018). Physiological, biochemical and molecular responses of lentil (Lens culinaris Medik.) genotypes under drought stress. Indian Journal of Plant Physiology. https://doi.org/10.1007/s40502-018-0411-7.

Sofi, P. A., Djanaguiraman, M., Siddique, K. H. M., \& Prasad, P. V. V. (2018). Reproductive fitness in common bean (Phaseolous vulgaris L.) under drought stress is associated with root length and volume. Indian Journal of Plant Physiology.

Subashini et al. (2018). Quantitative trait loci (QTL) for salinity tolerance traits in interspecific hybrids of Eucalyptus. Indian Journal of Plant Physiology. https://doi.org/10.1007/s40502018-0403-7.

Tanwar, A., Sharma, S., \& Kumar, S. (2018). Targeted genome editing in algae using CRISPR/Cas9. Indian Journal of Plant Physiology. https://doi.org/10.1007/s40502-018-0423-3.

Tribhuvan, K. U., Sandhya, Kumar, K., Sevanthi, A. M., \& Gaikwad K. (2018). MutMap: A versatile tool for identification of mutant loci and mapping of genes. Indian Journal of Plant Physiology. https://doi.org/10.1007/s40502-018-0417-1.

Vivitha, P., Raveendran, M., Vijayalakshmi, C., \& Vijayalakshmi, D. (2018). Genetic dissection of high temperature stress tolerance using photosynthesis parameters in QTL introgressed lines of rice cv. Improved white ponni. Indian Journal of Plant Physiology. https://doi.org/10.1007/s40502-018-0408-2. 